\title{
LIFE CYCLE ASSESSMENT ON LOG HARVESTING FROM NATURAL FOREST IN PENINSULAR MALAYSIA
}

\author{
Gan KS*, Zairul AR, Geetha R \& Khairul M \\ Forest Products Division, Forest Research Institute Malaysia, 52109 Kepong, Selangor, Malaysia \\ *ganks@frim.gov.my \\ Submitted July 2020; accepted October 2020
}

\begin{abstract}
The demand for wooden products are high due to its environmental benefits. Logs are harvested in a sustainable manner to meet the demand from local and international markets. However, resources consumption during logging activities impacts the environment. A life cycle assessment (LCA) was carried out to quantify the environmental impacts associated with log harvesting activities from natural forests in Peninsular Malaysia. Fuel consumption for each logging activity was obtained from several logging contractors for three different forest types, namely, hill forest, lowland forest and peat swamp forest. The harvesting systems and types of machines used in the different forest types were almost the same, except for the combination of equipment used, particularly in logging activity. Log harvesting in peat swamp forest generated the highest impact on global warming (49.69 $\left.\mathrm{kg} \mathrm{CO}_{2}-\mathrm{eq} \mathrm{m}^{-3}\right)$, acidification $\left(0.72 \mathrm{~kg} \mathrm{SO}_{2}-\mathrm{eq} \mathrm{m}^{-3}\right)$, eutrophication $\left(0.93 \mathrm{~kg} \mathrm{PO}_{4}\right.$-eq m$\left.{ }^{-3}\right)$ and photochemical ozone creation potentials $\left(0.27 \mathrm{~kg} \mathrm{C}_{2} \mathrm{H}_{2}\right.$-eq m$\left.{ }^{-3}\right)$ due to the high consumption of fuel to operate on-field machines for skidding. The terrain in every forest type was varied, and this influenced the amount of fuel used in harvesting.
\end{abstract}

Keywords: Forest operations, potential environmental impacts, fuel consumption, peat swamp forest, hill forest, lowland forest

\section{INTRODUCTION}

In Peninsular Malaysia, logs are mainly harvested from sustainably managed natural forest and a very small quantity, from the plantation forest. Depending on the elevation, logs from the natural forest can be harvested from the lowland forest $(<300 \mathrm{~m})$, hill forest $(300-750 \mathrm{~m})$, upperhill forest $(750-1000 \mathrm{~m})$ and peat swamp forest. The proportion of logs from each forest type corresponds closely to the forest land status which comprises state land/alienated land, permanent reserved forest (PRF), and national parks/state parks/wildlife and bird sanctuaries. Hill forest is mainly categorised under PRF while lowland forest and peat swamp forest are included under PRF and state/alienated land.

Forest harvesting activities in Peninsular Malaysia are managed under a forest management system. Since the Gutta-percha era, forestry management has gradually transformed to be in line with the current technological development and harvesting activities at that time. Currently, the harvesting activities in Peninsular Malaysia are implemented in accordance with the Sustainable Forest
Management (SFM) concept with priority given to environment and forest structure aspects. Selective Management System (SMS) is practised under the SFM in production forests within the PRF to ensure sustainable standing stock for the next 25 to 30 years of cutting cycle (Norizah et al. 2016). The harvesting activities following SMS are specifically divided into preharvesting, harvesting and post-harvesting, as briefly summarised in Table 1 .

Reduced impact logging (RIL) practice was also developed as a component to minimise impact to the forest ecosystem with sustainable timber harvesting prescriptions. RIMBAKA timber harvester was the most current modified excavator used under RIL to remove felled logs, and it has managed to reduce the use of heavy machines movement (Nazir Khan \& Mohd Yunus 2005). However, RIMBAKA is not used any longer since early this year due to high maintenance cost and unsuitable for logging activities at higher elevation (more than $700 \mathrm{~m}$ ) (Azian M 2020, personal communication). Other logging machines and equipment (axe, 
Table 1 Description of harvesting activities stages in Peninsular

Malaysia under Selective Management System

\begin{tabular}{ll}
\hline Activity & Description \\
\hline Pre-harvesting & - Pre-felling inventory \\
& - Cutting limit prescription \\
& - Timber tagging \\
Harvesting & - Road construction \\
& - Directional felling \\
Post-harvesting & - Timber transportation \\
& - Post-harvest assessment \\
& - Post-felling inventory \\
\hline
\end{tabular}

Source: Adapted from Nazir Khan and Mohd Yunus (2005)

chainsaw, tractor, crawler, powersaw, skidder, bulldozers and trucks) are still in use.

Harvested $\operatorname{logs}$ are processed into sawn timber and various wooden products for local and international markets. Demands are mainly attributable to the potential of wooden products to store carbon throughout their service life, and therefore have the potential to mitigate climate change which is contrary to steel, plastic and concrete (Abbas \& Handler 2018, Labelle \& Lemmer 2019). Wood is also categorised as carbon neutral or low greenhouse gases (GHGs) emission material (Labelle \& Lemmer 2019).

Although wood and wooden products provide environmental benefits, global concerns related to forest activities have been growing, particularly in regard to log harvesting. Although the advancement of mechanisation has reduced labour and costs for harvesting activities (Norizah et al. 2011), these technologies have negative impact on the environment. Forest activities may trigger environmental degradation as a result of resources consumption, namely, material, energy and water. In view of this, numerous studies have been conducted on the impacts of logging and timber processing activities on the environment using life cycle assessment (LCA) approach (Berg \& Karjalainen 2003, Abbas \& Handler 2018, Han et al. 2015, Labelle \& Lemmer 2019).

Several researchers have carried out studies of carbon related assessment in natural forest in this country (Pinard \& Putz 1997, Yashiro et al. 2008, Itoh et al. 2012, Saner et al. 2012, Azian et al. 2019). Nevertheless, these studies are significantly far from the concept of LCA. To date, there have been no scientific studies to assess the environmental profile from logging activities in Peninsular Malaysia using the methodological framework of LCA.

LCA is an analytical tool to assess the environmental performance and to identify the environmental hotspots in a product system. LCA is normally conducted for a product system from cradle-to-grave, by accounting all the environmental impacts from the resource extraction to end-of-life or disposal based on a series of LCA standards by ISO 14040 (ISO 2006a) and 14044 (ISO 2006b). LCA as defined by ISO 14040 and 14044 is compiling and evaluates input and output data, and the potential environmental impacts of a product system during the product lifespan. The result can be used for identifying opportunities to improve the environmental aspects of a product at various stages in its life cycle, and for decision making in industry and organisation in the selection of products for application and marketing (e.g. environmental claim, eco-labelling scheme or Environmental Product Declaration).

As LCA has become an important methodological framework to assess the impacts of timber activities on the environment, it is essential to carry out a preliminary study to assess the potential environmental impacts from logging activities. Therefore, this study was set out to establish an environmental profile for log production in Peninsular Malaysia to facilitate subsequent LCA studies on other wooden products. The assessment focused on the potential environmental impacts associated with $\log$ harvesting from three types of natural forest (hill forest, lowland forest and peat swamp forest). Based on the log production from these different forest types, a weighted average 
environmental impact of logs harvested from the natural forest in Peninsular Malaysia was estimated.

\section{MATERIALS AND METHODS}

LCA was used as a tool to assess the potential environmental impacts resulting from $\log$ harvesting in three forest types (Table 2). The methodological framework was conducted following the revised ISO 14040 and 14044 (ISO 2006a, b respectively).

\section{Descriptions of the system}

In 2018, the total area of PRF in Peninsular Malaysia was 4,803,350 ha, of which 4,344,781 ha was inland forest (lowland and hill forests), 253,447 ha was peat swamp forest, 89,684 ha mangrove forest and 115,438 ha plantation forest (FDPM 2019), and log production was $4,191,245 \mathrm{~m}^{3}$. Logs from the natural forest were mainly harvested from the inland forest and peat swamp forest. Based on this information, it was estimated that $90 \%$ of the log production was from hill forest (inland forest), $5 \%$ from lowland forest (alienated land/state land) and $5 \%$ from the peat swamp forest. These proportions of $\log$ production were used as the basis for the weighted average estimate of the environmental performance for unit log harvested from natural forests in Peninsular Malaysia.

Harvesting activities in lowland forest, peat swamp forest and hill forest were similar. The harvesting activities was carried out in teams, where each team comprised one feller and skidder. The number of teams differed based on $\log$ harvesting area. In this study, surveys were conducted at several logging sites involving several respondents (contractors who were given the license to carry out logging activities in large areas) to determine resource consumption during log harvesting activities at lowland forest, peat swamp forest and hill forest (Table 2).

\section{Hill forest and lowland forest}

Forest roads were constructed and maintained using the bulldozer or crawler tractor. Trees were felled and bucked using chainsaw, and logs were skidded by crawler tractor to a sublanding (intermediate logyard) in the forest. Winch lorry was used for short distance haulage between the sublandings and main landing site. A wheeled loader (log grapple) was used to manage the logs at the main landing site. The logging operation was supported by a logging camp and fourwheel drive pick-up trucks for transportation of workers.

\section{Peat swamp forest}

In previous time, logging in peat swamp forest had a network of locomotive rail for $\log$ transportation. However, this feature is not common nowadays because the forest and the trunk road system are in the same vicinity. Temporary forest road is built to connect the trunk road and logging sites. Trees were felled and bucked using chain saw and the logs are then skidded from the felling site to the sublanding by an excavator. The loading of logs into the winch lorry was done using the excavator. Winch lorry was used for short-distance haulage between the sublanding and main landing site. Unloading and stacking of logs at the main landing site was carried out using a wheeled loader. Similar to the hill and lowland forests, the operation at the peat swamp forest was supported by a logging camp and four-wheel drive pick-up trucks for transportation.

Table 2 Number of respondents according to study sites and types of forest

\begin{tabular}{lllc}
\hline Location & Forest type & Forest status & $\begin{array}{c}\text { No. of } \\
\text { respondent }\end{array}$ \\
\hline Mersing, Johor & Lowland forest & Permanent reserved forest & 2 \\
Rompin, Pahang & Peat swamp forest & State land (land-use conversion) & 3 \\
Grik, Perak & Hill forest & Permanent reserved forest & 3 \\
Kuala Berang, Terengganu & Hill forest & Permanent reserved forest & 5 \\
Jeli, Kelantan & Hill forest & Permanent reserved forest & 4 \\
\hline
\end{tabular}




\section{System boundary}

System boundary for the harvested logs from the natural forest is shown in Figure 1. The input, output and environmental emissions were accounted from cradle-to-gate. Logging activities began with the operation of camps at the logging sites. The gate of the system was the main landing site where logs would be transported to various processing plants. The input into the system was mainly fuels, i.e. petrol and diesel for the various machineries employed during the logging operation. The output was logs, and the various emissions were from the combustion of fuels.

\section{Functional unit}

The investigated product for this study was harvested logs. In the logging sector and industry utilising logs from the natural forest, the imperial measurement unit for the volume of logs is Hoppus ton. In contrast, logs from the plantation forest for wood composite, and pulp and paper products are measured by weight in metric tonne. In this study, the functional unit for the assessment of potential environmental impacts was standardised as per unit volume basis for $1 \mathrm{~m}^{3}$ of harvested logs. All the different log measurement units were converted to cubic meter.

\section{Data collection}

Surveys were conducted among logging contractors at the logging sites. Data collected comprised types of machinery used and fuel consumption for each activity. Petrol was used for electricity generator set, water pump and chainsaw, while other machineries such as crawler tractors, wheeled loaders, excavators and winch lorry used diesel. The lubricant consumption was prorated as $0.5 \%$ of fuel consumption.

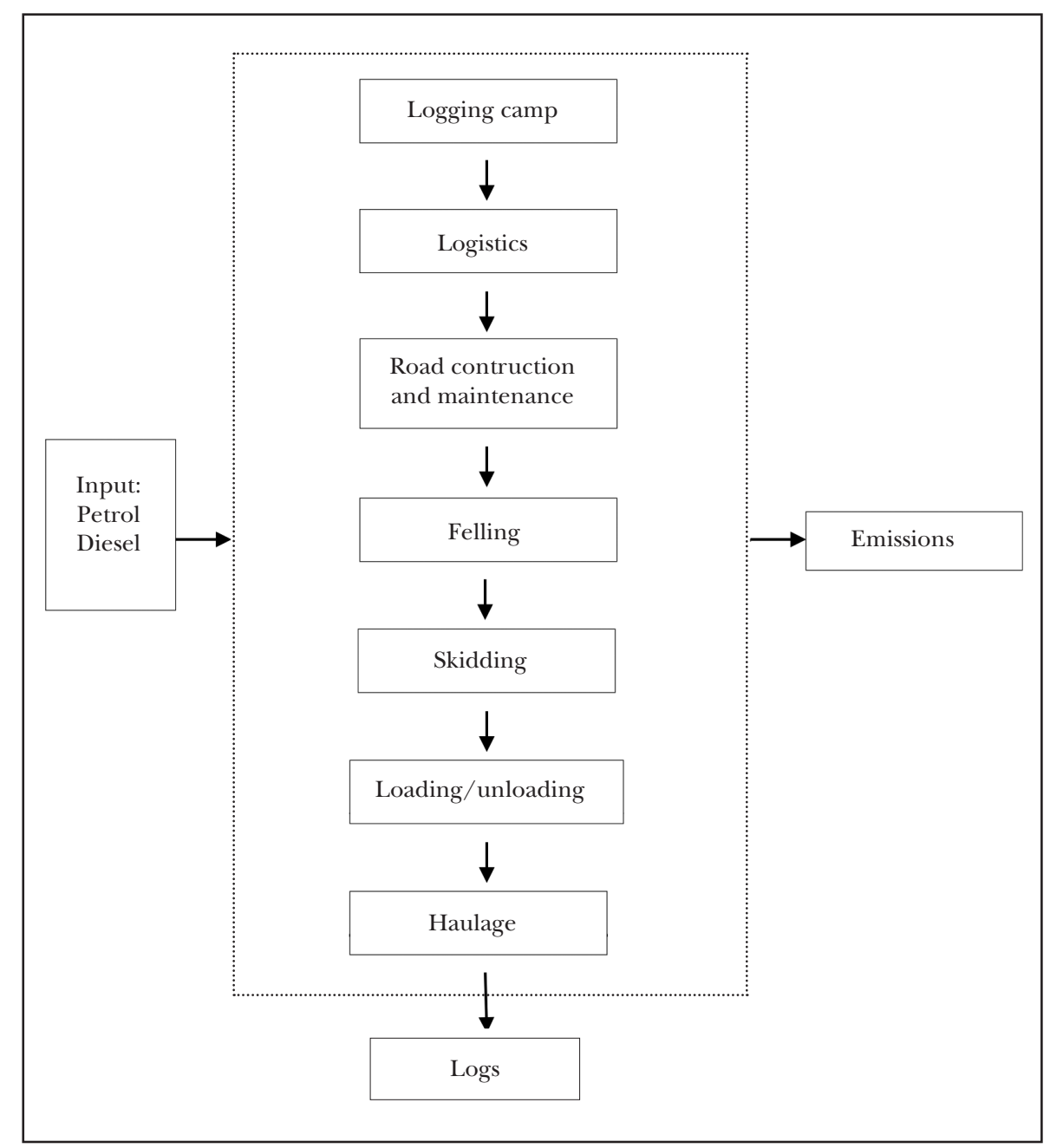

Figure 1 System boundary for log harvesting activities in Peninsular Malaysia 
Once the inputs were identified, the emissions to the environment was calculated based on the following equation (Ramasamy et al. 2015):

$$
\begin{aligned}
& \text { Environmental } \\
& \text { emissions }
\end{aligned}=\begin{aligned}
& \text { Activity } \\
& \text { data }
\end{aligned} \times \begin{aligned}
& \text { emission } \\
& \text { factor }
\end{aligned}
$$

Activity data was related to the on-site measurement of the inputs. Emission factors used for calculating emissions associated with the consumption of fuel are listed in Table 3. For life cycle impact assessment (i.e. the assessment of potential environmental impact categories), four impact categories were quantified based on the characterisation units in Table 4. The impact categories were global warming potential, acidification potential, eutrophication potential, and photochemical ozone creation potential. These emission factors and impact categories characterisation units were adopted from Adu and Eshun (2014).

\section{Allocation approach}

Allocation is defined as the partitioning of environmental loads among the final products.
In this study, logging activities produced logs and forest residues such as tops, limbs and undersized trees which were left in the forest. Therefore, it was decided that no co-products were produced in this study and excluded from the system boundary. The final product was harvested logs only. Therefore, the environmental loads were allocated to the harvested logs only.

\section{RESULTS AND DISCUSSION}

\section{Potential environmental impacts}

The potential environmental impacts evaluated in this study were global warming potential, acidification potential, eutrophication potential and photochemical ozone creation potential. The selection of the potential impact categories was deemed on the fact that these were the most common categories applied in LCA studies for forest activities (González-García et al. 2013). Figure 2 depicts the findings of the potential environmental impacts associated with logging activities at hill forest, lowland forest and peat swamp forest. Peat swamp forest had the highest contribution to global warming potential, acidification potential, eutrophication potential

Table 3 Emission factors for the calculation of the emissions from fuel consumed

\begin{tabular}{lcc}
\hline Fuel & $\begin{array}{c}\text { Compound } \\
\text { emitted }\end{array}$ & $\begin{array}{c}\text { Emission factor } \\
\left(\mathrm{g} \mathrm{kg}^{-1} \text { fuel }\right)\end{array}$ \\
\hline Petrol & $\mathrm{CO}_{2}$ & 3172.00 \\
& $\mathrm{CO}$ & 14.07 \\
& $\mathrm{~N}_{2} \mathrm{O}$ & 0.02 \\
$\mathrm{CH}_{4}$ & 7.67 \\
$\mathrm{NO}_{\mathrm{x}}$ & 1.55 \\
$\mathrm{NMVOC}^{\text {Diesel }}$ & $\mathrm{SO}_{2}$ & 762.00 \\
& $\mathrm{CO}_{2}$ & 0.07 \\
& $\mathrm{~N}_{2} \mathrm{O}$ & 3150.00 \\
$\mathrm{CH}_{4}$ & 0.02 \\
& $\mathrm{NO}_{\mathrm{x}}$ & 6.91 \\
& $\mathrm{NMVOC}$ & 50.00 \\
& $\mathrm{SO}_{2}$ & 6.50 \\
& $\mathrm{CO}$ & 15.00 \\
& & 14.00 \\
\hline
\end{tabular}

Source: Adapted from Adu and Eshun (2014); the name of compounds are as in Table 4 
Table 4 Life cycle impact assessment categories and indicators

\begin{tabular}{|c|c|c|c|c|}
\hline $\begin{array}{l}\text { Potential impact } \\
\text { category }\end{array}$ & Scale & Classification & Characterisation factor & $\begin{array}{l}\text { Description of } \\
\text { characterisation factor }\end{array}$ \\
\hline $\begin{array}{l}\text { Global warming } \\
\text { potential }\end{array}$ & Global & $\begin{array}{l}\text { Carbon dioxide } \\
\left(\mathrm{CO}_{2}\right) \\
\text { Methane }\left(\mathrm{CH}_{4}\right) \\
\text { Nitrous oxide }\left(\mathrm{N}_{2} \mathrm{O}\right)\end{array}$ & $\begin{array}{l}1 \mathrm{~kg}=1 \mathrm{CO}_{2}-\mathrm{eq} \\
1 \mathrm{~kg}=21 \mathrm{CO}_{2}-\mathrm{eq} \\
1 \mathrm{~kg}=310 \mathrm{CO}_{2}-\mathrm{eq}\end{array}$ & $\begin{array}{l}\text { Converts life cycle } \\
\text { iventory (LCI) data to } \\
\mathrm{CO}_{2} \text { equivalents }\end{array}$ \\
\hline $\begin{array}{l}\text { Acidification } \\
\text { potential }\end{array}$ & Regional & $\begin{array}{l}\text { Sulfur dioxide }\left(\mathrm{SO}_{2}\right) \\
\text { Nitrogen oxides } \\
\left(\mathrm{NO}_{\mathrm{x}}\right)\end{array}$ & $\begin{array}{l}1 \mathrm{~kg}=1 \mathrm{SO}_{2}-\mathrm{eq} \\
1 \mathrm{~kg}=0.7 \mathrm{SO}_{2}-\mathrm{eq}\end{array}$ & $\begin{array}{l}\text { Converts LCI data to } \\
\mathrm{SO}_{2} \text { equivalents }\end{array}$ \\
\hline $\begin{array}{l}\text { Eutrophication } \\
\text { potential }\end{array}$ & Regional & $\mathrm{NO}_{\mathrm{x}}$ & $1 \mathrm{~kg}=1.3 \mathrm{PO}_{4}-\mathrm{eq}$ & $\begin{array}{l}\text { Converts LCI data to } \\
\mathrm{PO}_{4} \text { equivalents }\end{array}$ \\
\hline $\begin{array}{l}\text { Photochemical } \\
\text { ozone creation } \\
\text { potential }\end{array}$ & Local & $\begin{array}{l}\text { Non-methane } \\
\text { hydrocarbon } \\
\text { (NMVOC) } \\
\text { Carbon monoxide } \\
(\mathrm{CO}) \\
\mathrm{CH}_{4} \\
\mathrm{NO}_{\mathrm{x}}\end{array}$ & $\begin{array}{l}1 \mathrm{~kg}=0.416 \mathrm{C}_{2} \mathrm{H}_{2}-\mathrm{eq} \\
1 \mathrm{~kg}=0.027 \mathrm{C}_{2} \mathrm{H}_{2}-\mathrm{eq} \\
1 \mathrm{~kg}=0.006 \mathrm{C}_{2} \mathrm{H}_{2}-\mathrm{eq} \\
1 \mathrm{~kg}=0.028 \mathrm{C}_{2} \mathrm{H}_{2}-\mathrm{eq}\end{array}$ & $\begin{array}{l}\text { Converts LCI data to } \\
\text { ethylene equivalents }\end{array}$ \\
\hline
\end{tabular}

Source: Adapted from Adu and Eshun (2014)

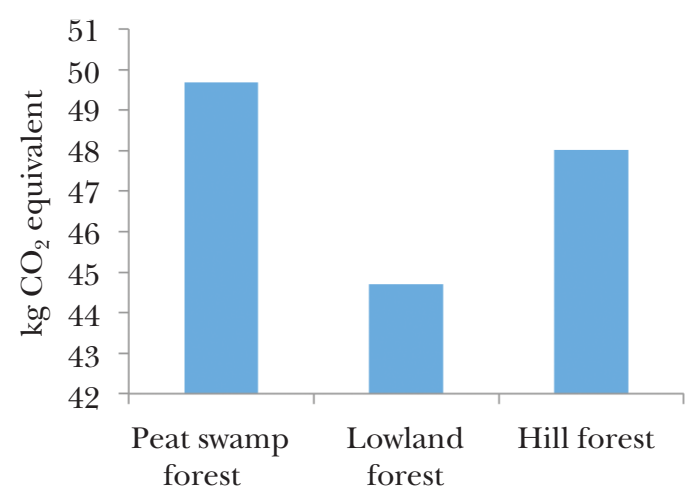

(a)

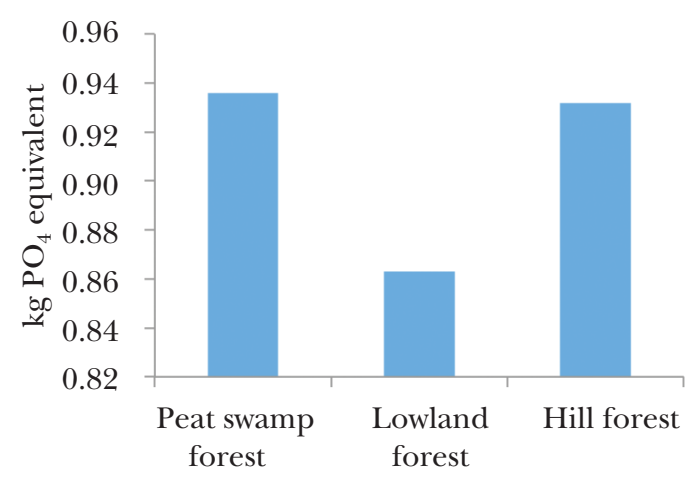

(c)

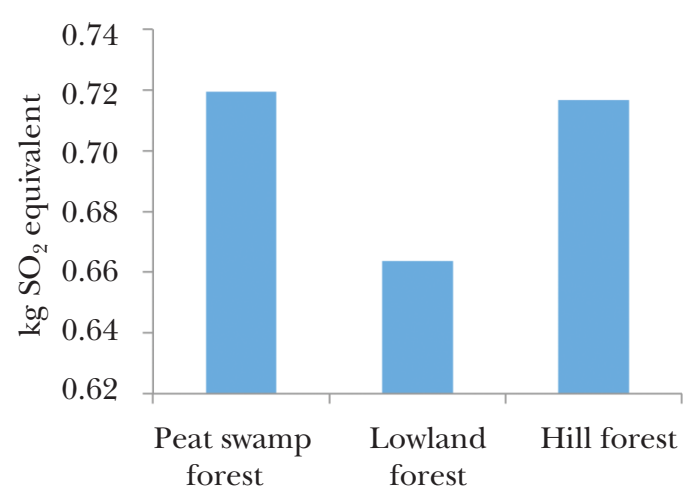

(b)

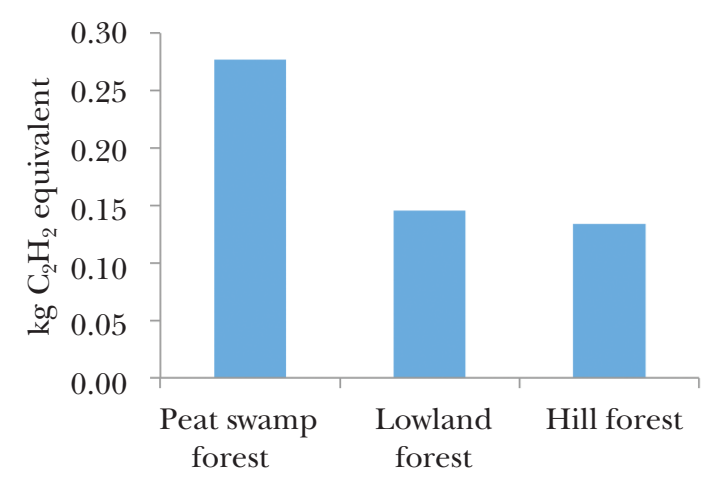

(d)

Figure 2 Potential environmental impacts associated with logging activities in three different forest types: (a) global warming potential, (b) acidification potential, (c) eutrophication potential and (d) photochemical ozone creation potential on basis of per $\mathrm{m}^{3}$ of harvested logs 
and photochemical ozone creation potential. For photochemical ozone creation potential, the level of emission for peat swamp forest harvesting operation was about double that of hill forest and lowland forest. Differences in the environmental profiles between hill forest and lowland forest were not substantial.

Figure 3 shows the percentage of the potential environmental impacts associated with logging activities in the three forest types. Logging activities for peat swamp forest, lowland forest and hill forest were comparable, comprising logging camps, logistics, felling, road construction and maintenance, skidding, loading and unloading and short distance haulage. Nevertheless, the percentages of the potential environmental impacts were different. The use of resources varied according to logging activities in each forest type. Resources consumption consequently impacts the environment (Berg \& Karjalainen 2003, González-García et al. 2013, Han et al. 2015, Oneil \& Puettmann 2017). In this study, diesel and petrol were the only resources used for log harvesting activities in the three forest types. Fuel, which is used to operate harvesting machines and equipment, is the main resource used in logging activities (Oyier \& Visser 2016). The types of harvesting machines employed in the different forest types were similar although the number of fellers and machineries may vary. Figure 4 shows the proportion of fuel consumption by activity during log harvesting in the three forest types. Logging activities in peat swamp forest consumed the most fuel probably due to the forest conditions. A high percentage of fuel was used for skidding and loading/unloading activities. The main equipment used was the excavator which is multi-functional for the forest condition but less productive compared with the crawler tractors in dry inland forest (hill and lowland forests). Steeper terrain at hill forest resulted in slightly higher consumption of fuel than lowland forest. The use of fuel for different types of machines and harvesting systems are affected by terrain and stand characteristics of the trees (Oyier \& Visser 2016).

Fuel comprises carbon, sulphur, nitrogen or their compounds. The combustion of fuel sources will release these elements which consequently create several environmental concerns as combustion of fuel sources releases GHGs to the environment (Berg \& Karjalainen 2003).

\section{Comparison with previous studies}

A considerable number of studies of the potential environmental impacts associated with forest activities have been reported. For this comparison, the focus of this study was the potential of global warming. Global warming potential has been highlighted as the highest environmental impact profile (Tellnes et al. 2012). The release of GHGs mainly carbon dioxide $\left(\mathrm{CO}_{2}\right)$ is linked to the combustion of fuel used to operate machines and equipment (Berg \& Karjalainen 2003). Therefore, the assessment of global warming potential has become a growing interest at the international level due to the efforts to reduce carbon emission to the environment.

The findings of global warming potential related to logging activities from other studies are shown in Table 5. The assessment of global warming potential in the present study was comparatively higher than the other studies. However, comparison studies are reasonably challenging as there are several aspects that need to be taken into account (González-García et al. 2013, Han et al. 2015), one of which was the log species. Log species from natural forest mainly belong to the family Dipterocarpaceae. The allowable cutting diameter of hardwood $\operatorname{logs}$ in the natural forest is usually $\geq 60 \mathrm{~cm}$ for dipterocarp species and $\geq 45 \mathrm{~cm}$ for nondipterocarp species. Densities of tropical hardwood are high, i.e. $>880,720-880$ and $>720 \mathrm{~kg} \mathrm{~m}^{-3}$ for heavy hardwood, medium hardwood and light hardwood respectively (Menon 2000). On the contrary, most of the species from the other studies are plantationgrown softwoods. Plantation-grown softwood from temperate regions are less dense in comparison with tropical hardwood. Therefore, cutting force increases consistently with higher density of logs. Size of the logs and density generally influence the energy use, and thus more fuel is required to cut down bigger logs with higher densities (Ratnasingam et al. 2015).

Logging methods in different regions are different depending on forest conditions, soil moisture conditions and soil stability, and tree stand characteristics (Han et al. 2015, Laschi et al. 2016, Oneil \& Puettmann 2017). Generally, the felling of logs uses either a motor-manual system or mechanical system, the former being the more efficient (Berg and Karjalainen 2003). Meanwhile, extractions of felled logs to the 
Peat swamp forest
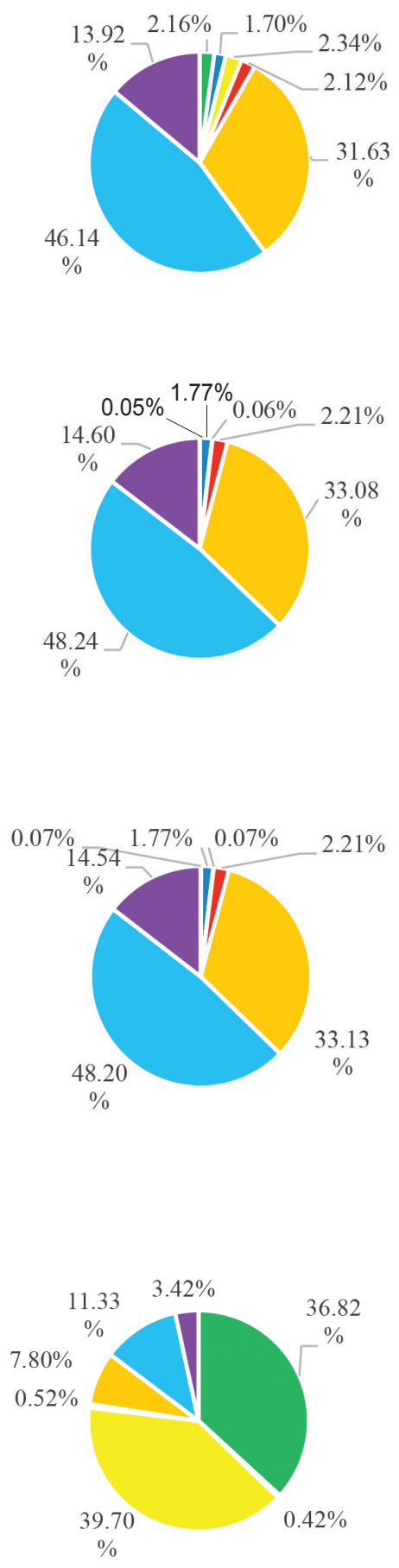

Legend

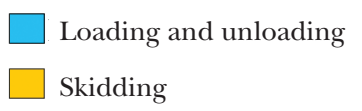

Road construction and maintenance

\section{Felling}

Lowland forest

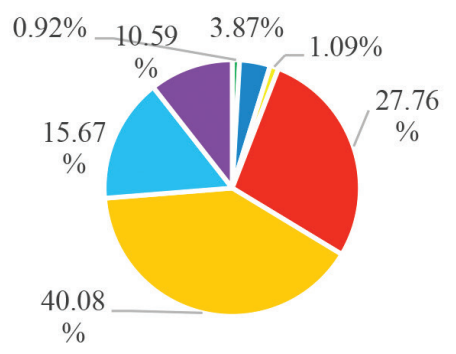

(a)

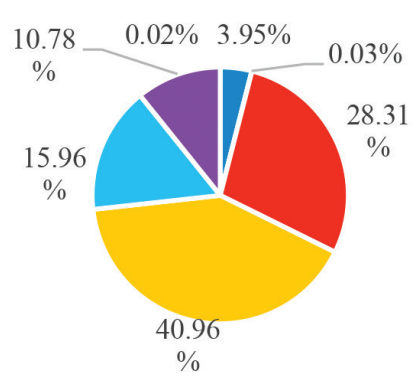

(b)

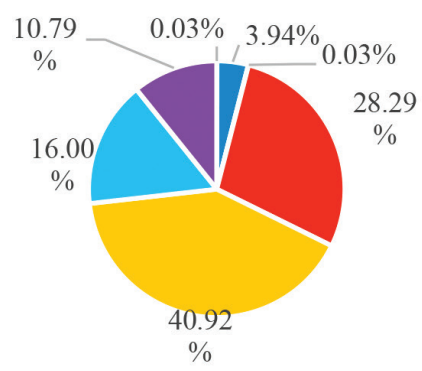

(c)

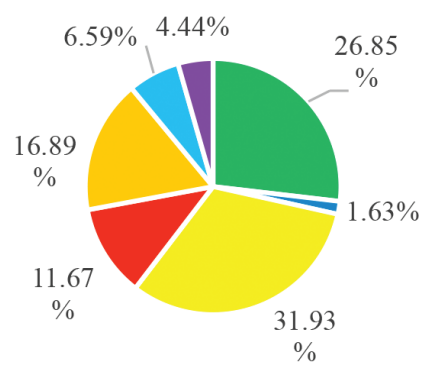

(d)
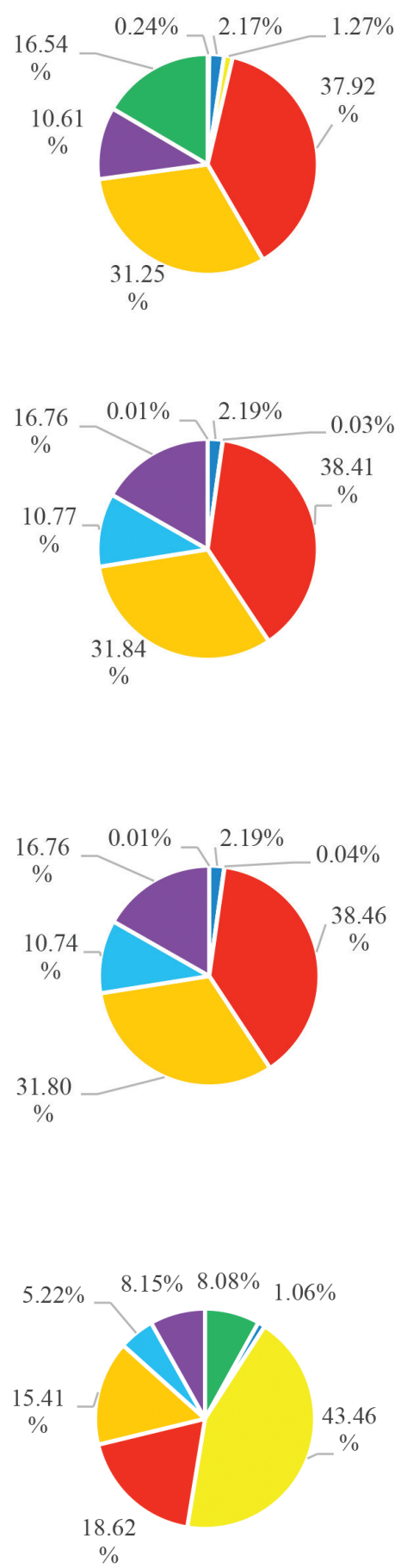

Figure 3 Percentage of potential environmental impacts by logging activities in peat swamp forest, lowland forest and hill forest: (a) global warming potential, (b) acidification potential, (c) eutrophication potential and (d) photochemical ozone creation potential 


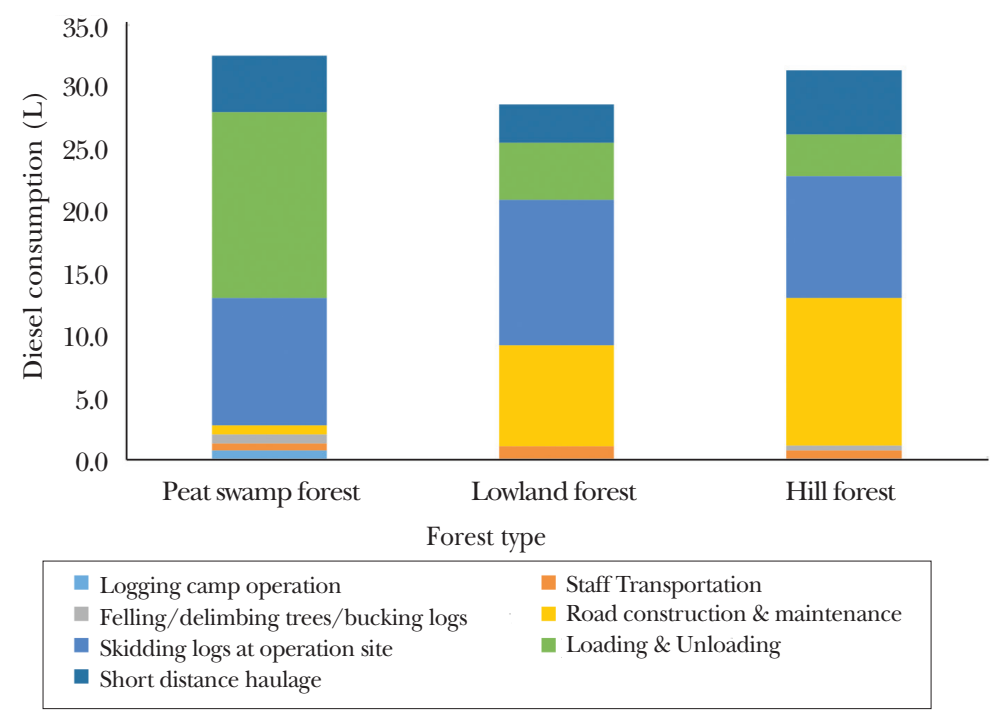

Figure 4 Fuel consumption during log harvesting activities

Table 5 Comparison of global warming potential with previous studies

\begin{tabular}{|c|c|c|c|c|c|c|}
\hline Reference & $\begin{array}{l}\text { Global warming } \\
\text { potential } \\
\left(\mathrm{kg} \mathrm{CO}_{2} \text {-eq m}{ }^{-3}\right)\end{array}$ & Type of forest & Species & Region & Further use & Logging method \\
\hline Present study & $\begin{array}{l}49.7 \\
44.7 \\
48.0\end{array}$ & $\begin{array}{l}\text { Peat swamp forest } \\
\text { Lowland forest } \\
\text { Hill forest }\end{array}$ & $\begin{array}{l}\text { Mixed } \\
\text { species }\end{array}$ & $\begin{array}{l}\text { Peninsular } \\
\text { Malaysia }\end{array}$ & Sawmill & $\begin{array}{l}\text { - Mechanised ground- } \\
\text { based harvesting } \\
\text { - } \quad \text { Selective cutting }\end{array}$ \\
\hline $\begin{array}{l}\text { Oneil and } \\
\text { Puettmann } \\
(2017)\end{array}$ & $10.74-18.14$ & $\begin{array}{l}\text { Temperate } \\
\text { coniferous } \\
\text { rainforest }\end{array}$ & $\begin{array}{l}\text { Douglas } \\
\text { fir }\end{array}$ & USA & $\begin{array}{l}\text { Industrial } \\
\text { roundwood }\end{array}$ & $\begin{array}{l}\text { - Ground-based and } \\
\text { cable-based harvesting } \\
\text { system } \\
\text { - Commercial thinning }\end{array}$ \\
\hline $\begin{array}{l}\text { Han et al. } \\
(2015)\end{array}$ & 17.13 & Forest & Redwood & $\begin{array}{l}\text { Northern } \\
\text { California }\end{array}$ & Sawmill & $\begin{array}{l}\text { Manual ground-based, } \\
\text { skyline and helicopter } \\
\text { harvesting methods }\end{array}$ \\
\hline $\begin{array}{l}\text { Handler et al. } \\
\text { (2014) }\end{array}$ & $9.9-14.7$ & $\begin{array}{l}\text { Natural hardwood } \\
\text { stands } \\
\text { Natural softwood } \\
\text { stands } \\
\text { Mixed hardwood/ } \\
\text { softwood stands } \\
\text { Softwood } \\
\text { plantation }\end{array}$ & $\begin{array}{l}\text { Mixed } \\
\text { species }\end{array}$ & Michigan & Pulpwood & 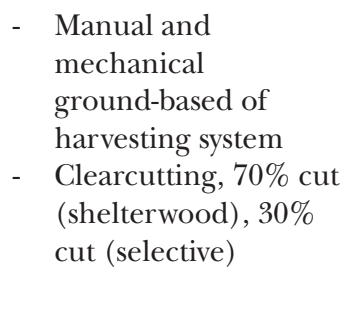 \\
\hline $\begin{array}{l}\text { Adu and } \\
\text { Eshun (2014) }\end{array}$ & 73.35 & $\begin{array}{l}\text { Natural tropical } \\
\text { forest }\end{array}$ & Khaya & Ghana & Sawmill & $\begin{array}{l}\text { Mechanised harvesting } \\
\text { method }\end{array}$ \\
\hline $\begin{array}{l}\text { González } \\
\text { García et al. } \\
\text { (2013) }\end{array}$ & 2.35 & Forest plantation & $\begin{array}{l}\text { Douglas } \\
\text { fir }\end{array}$ & Germany & $\begin{array}{l}\text { Biomass } \\
\text { production }\end{array}$ & $\begin{array}{l}\text { - Manual and } \\
\text { mechanical ground- } \\
\text { based of harvesting } \\
\text { system } \\
\text { - } \begin{array}{l}\text { Thinning and final } \\
\text { cutting }\end{array}\end{array}$ \\
\hline $\begin{array}{l}\text { Berg and } \\
\text { Karjaleinen } \\
(2003)\end{array}$ & $\begin{array}{c}10.6 \\
9.1\end{array}$ & Forest plantation & $\begin{array}{l}\text { Mixed } \\
\text { species }\end{array}$ & $\begin{array}{l}\text { Finland } \\
\text { Sweden }\end{array}$ & & 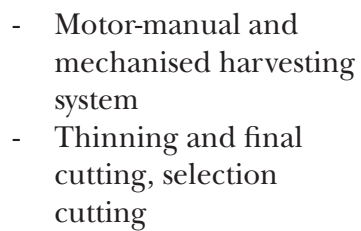 \\
\hline
\end{tabular}


landing site substantially used different machines. Hence, with varying degrees of mechanisation in the logging activities, it was difficult to make a comparison.

Another aspect that needed to be observed was the differences in forest management. In Peninsular Malaysia, natural forest is selfgenerated. Following this, logging activities in the natural forest in Peninsular Malaysia are based on SMS, whereby the felling cycle is from 25-30 years and the cutting limit for dipterocarp species is $\geq$ $60 \mathrm{~cm}$ while non-dipterocarp, $\geq 45 \mathrm{~cm}$. In some countries, thinning is carried out to reduce the damage of residual standing trees. Thinning resulted in higher global warming potential than clear cutting operations (Han et al. 2015), although each region has its own practices of thinning (Berg \& Karjalainen 2003).

System boundary was set up to observe the flow of the input, output and environmental emissions during an activity. The present study focused on harvesting activities with inclusion of logging camp operation, logistics and maintenance of existing logging road. On the other hand, the system boundaries from the previous studies were from silvicultural to harvesting operation (Oneil \& Puettmann 2017), forest operations to secondary transportation (Berg \& Karjaleinen 2003), greenhouse grown seedlings to transport logs to mill (Han et al. 2015), site preparation stage to the loading of the logs onto truck at the roadside (González-García et al. 2013) and felling to transportation (Laschi et al. 2016). The choices of the activities included in the system boundary influence the use of resources. A study was carried out by Berg and Karjalainen (2003) to compare the environmental loads between Finland and Sweden, where both countries had similar system boundary and technology used. The result clearly indicated variations in operations, technology and the fuel quality. Thus, even though there may be similarity in the system boundary, it is difficult to highlight the comparison observed due to variations in yield per hectare, management intensity and harvest system.

\section{CONCLUSIONS}

This assessment of potential environmental impacts during log harvesting in Peninsular Malaysia is a pioneer study. The activities began with the operation in a logging camp, logistics, tree felling, road construction and maintenance, skidding, loading and unloading, and end with short distance haulage. Based on the estimated log production from each forest type, the weighted average environmental impacts for log harvested from each of the natural forest were established. Peat swamp forest had the highest impact on the environment, followed by hill forest and lowland forest. Differences in environmental impacts for logs harvested from the three forest types were not substantial. The combustion of fuel sources during logging activities produced environment emissions. The differences in the amount of fuel used in the three types of forest were due to forest conditions. These quantified environmental impacts could be further utilised for LCA study of wooden products made from logs harvested from Peninsular Malaysia.

\section{ACKNOWLEDGEMENTS}

The authors would like to thank the Forestry Department Peninsular Malaysia and State Forest Departments of Kelantan, Pahang, Perak, Selangor and Terengganu for logistic facilities and technical assistance.

\section{REFERENCES}

Abbas D \& Handler RM. 2018. Life-cycle assessment of forest harvesting and transportation operations in Tennessee. Journal of Cleaner Production 176: 512-520.

ADU GA \& EsHun JF. 2014. Life Cycle Assessment for Environmental Product Declaration of Tropical African Mahogany (KHAYA) Lumber Produced in Ghana. International Tropical Timber Organization, Yokohama.

Azian M, Nizam MS, Samsudin M et al. 2019. Carbon emission assessment from different logging activities in production forest of Pahang, Malaysia. Journal of Tropical Forest Science 31: 304-311.

Berg S \& Karjalainen T. 2003. Comparison of greenhouse gas emissions from forest operations in Finland and Sweden. Forestry 76: 271-284.

FDPM (Forestry Department Peninsular Malaysia). 2019. Forestry Statistics Peninsular Malaysia 2019. FDPM, Kuala Lumpur.

González-García S, Krowas I, Becker G, Feijoo G \& MoreIRA MT. 2013. Cradle-to-gate life cycle inventory and environmental performance of Douglas-fir roundwood production in Germany. Journal of Cleaner Production 54: 244-252.

Han H-S, Oneil E, Bergman RD, Eastin IL \& Johnson LR. 2015. Cradle-to-gate life cycle impacts of redwood forest resource harvesting in northern California. Journal of Cleaner Production 99: 217-229.

Handler RM, Shonnard DR, Lautala P, Abbas D \& Srivastava A. 2014. Environmental impacts of roundwood supply chain options in Michigan: life-cycle 
assessment of harvest and transport stages. Journal of Cleaner Production 76: 64-73.

isO (International Organization For Standardization). 2006a. ISO 14040. International Standard Environmental Management - Life Cycle Assessment: Principles and Framework. Second Edition. ISO Copyright Office, Geneva.

ISO. 2006b. ISO 14044. International Standard Environmental Management - Life Cycle Assessment: Requirement and Guidelines. ISO Copyright Office, Geneva.

Itoh M, Kosugi Y, Takanashi S et al. 2012. Effects of soil water status on the spatial variation of carbon dioxide, methane and nitrous oxide fluxes in tropical rain-forest soils in Peninsular Malaysia. Journal of Tropical Ecology 28: 557-570.

LABELle ER \& Lemmer KJ. 2019. Selected environmental impacts of forest harvesting operations with varying degree of mechanization. Croatian Journal of Forest Engineering 40: 239-257.

Laschi A, Marchi E \& González-García S. 2016. Forest operations in coppice: environmental assessment of two different logging methods. Science of the Total Environment 562: 493-503.

Menon PKB. 2000. Struktur dan Pengecaman Kayu-Kayan di Malaysia. Dewan Bahasa dan Pustaka, Kuala Lumpur.

NAZIR Khan NK \& Mohd Yunus Z. 2005. Forest resources trend and sustainable forest management in Peninsular Malaysia. The Malaysian Forester 68: 138-153.

Norizah K, Mohd-Hasmadi I, Husna S \& Chung W. 2016. Log hauling productivity in timber harvesting operation in Peninsular Malaysia Forest. Journal of Tropical Forest Science 28: 207-216.
Norizah K, Mohd-Hasmadi I, Kamaruzaman J \& Alias MS. 2011. Evolution and development of forest harvesting in Peninsular Malaysia. The Malaysian Forester 74: 79-102.

Oneil E \& Puettmann ME. 2017. A life-cycle assessment of forest resources of the Pacific Northwest, USA. Forest Products Journal 67: 316-330.

Oyier P \& Visser R. 2016. Fuel consumption of timber harvesting systems in New Zealand. European Journal of Forest Engineering 2: 67-73.

Pinard M \& Putz F. 1997. Monitoring carbon sequestration benefits associated with a Reduced-Impact Logging Project in Malaysia. Mitigation and Adaptation Strategies for Global Change 2: 203-215.

Ramasamy G, Ratnasingam J, Bakar ES, Halis R \& Muttiah N. 2015. Assessment of environmental emissions from sawmilling activity Malaysia. Bioresources 10: 6643-6662.

Ratnasingam J, Ramasamy G, Toong W, Senin AL, Kusno MA \& Muttiah N. 2015. An assessment of the carbon footprint of tropical hardwood sawn timber production. Bioresources 10: 5174-5190.

Saner P, Yen YL, Robert CO \& Hector A. 2012. Carbon stocks and fluxes in tropical lowland dipterocarp rainforests in Sabah, Malaysian Borneo. PlosOne 7: 1-11.

Tellnes LGF, Nyrud AQ \& Flaete PO. 2012. Carbon footprint of products from Norwegian sawmilling industry. Paper presented at the biennial meetings of the Scandinavian Society of Forest Economics. 23-26 May 2012, Hyytiälä.

Yashiro Y, Kadir WR, OKuda T \& Koizumi H. 2008. The effects of logging on soil greenhouse gas $\left(\mathrm{CO}_{2}, \mathrm{CH}_{4}, \mathrm{~N}_{2} \mathrm{O}\right)$ flux in a tropical rain forest, Peninsular Malaysia. Agricultural and Forest Meteorology 148: 799-806. 